\title{
MITIGASI RESIKO KREDIT PERBANKAN
}

\author{
Fitriani Jamaluddin \\ Fakultas Syariah, IAIN Palopo \\ Email : Fitrianijamaluddin16@gmail.com
}

\begin{abstract}
There are two purpose of this research : (1) To explain the law risk that can arise in giving loan by Banking. (2) To explain the form of risk mitigation by Banking. This research is normative research. And the type of this research is library research. The result of this research, noticing banking sector is a high risk sector, it means that susceptible to risk, one of the risks that really hard to handle is loan risk. Banking should do some deep analysis before giving the loan, by using 4P, 5C, and 3R Principle Keyword : Risk Mitigation, Credit, Banking
\end{abstract}

\begin{abstract}
Abstrak
Tujun penelitian ini adalah (1) untuk menjelaskan resiko hukum yang muncul dalam hal pemberian kredit oleh Perbankan, (2) Untuk menjelaskan bentuk mitigasi resiko kredit oleh perbankan. Sifat penelitian yang digunakan adalah penelitian normatif, dan jenis penelitian adalah penelitian kepustakaan. Hasil penelitian menunjukkan bahwa Sektor Perbankan merupakan sektor yang sangat High Risk, artinya sangat rentan terhadap resiko-resiko, salah satu resiko yang sangat sulit untuk dihindari adalah resiko di bidang perkreditan. Pihak bank harus melakukan analisis yang cukup mendalam sebelum menyalurkan kredit dengan menggunakan prinsip 4P, 5C, dan 3R.
\end{abstract}

\section{Kata Kunci : Mitigasi Resiko, Kredit, Perbankan}

\section{PENDAHULUAN}

Keberadaan Perbankan merupakan hal yang sangat strategis dalam pembangunan nasional suatu negara. Perbankan menjadi salah satu indikator dalam pertumbuhan ekonomi, keberadaan Bank sebagai perekonomian yang bersifat Makro. Peran Perbankan tidak hanya terbatas pada badan yang bertujuan untuk memperoleh keuntungan (profit) namun keberadaan Perbankan mempunyai fungsi yang strategis dalam hal pembangunan nasional berupa kesejahteraan rakyat.

Di Indonesia Perbankan diatur dalam Undang-Undang Nomor 10 Tahun 1998 Tentang Perubahan Atas Undang-Undang Nomor 7 Tahun 1992 Tentang Perbankan, dan dalam Pasal 4 disebutkan bahwa Perbankan Indonesia bertujuan menunjang pelaksanaan pembangunan nasional dalam rangka meningkatkan pemerataan, 
pertumbuhan ekonomi, dan stabilitas nasional kearah peningkatan kesejahteraan rakyat banyak.

Kegiatan Perbankan terdiri dari Funding dan Landing, yaitu berupa kegiatan menghimpun dana dari masyarakat dan menyalurkan dana ke masyarakat. ${ }^{1}$ Penyaluran dana kepada nasabah dilakukan dalam bentuk pemberian kredit. Dalam Undang-Undang Perbankan Pasal 1 angka 11, Kredit merupakan penyediaan uang atau tagihan yang dapat dipersamakan dengan itu, berdasarkan persetujuan atau kesepakatan pinjam meminjam antara bank dengan pihak lain yang mewajibkan pihak meminjam untuk melunasi utangnya setelah jangka waktu tertentu dengan jumlah bunga.

Kredit yang disalurkan bank (konvensional) merupakan bagian terbesar dari aset yang dimiliki bank bersangkutan. Dalam kondisi perekonomian yang normal kredit dapat mencapai $70 \%$ sampai dengan $90 \%$ dari aset bank. Oleh karena itu perkreditan merupakan tulang punggung atau kegiatan utama bank. ${ }^{2}$

Kredit disamping kegiatan pengerahan dana dan masyarakat merupakan kegiatan utama dari bank-bak umum di Indonesia karena dua alasan $:^{3}$

a. Bunga kredit merupakan sumber-sumber pendapatan utama

b. Dalam kegiatann penyaluran kredit sumber dana dari kredit itu berasal terutama dari dana-dana yang dikerhkan oleh bank dari masyarakat.

Dalam penyaluran kredit terbentuk hubungan yang kompleks antara Bank selaku kreditur dan nasabah selaku debitur. Hubungan kompleks yang muncul antara bank dan nasabah di landasi oleh kepercayaan antara kedua belah pihak. Pemberian kredit oleh bank kepada nasabah yang menjadi pondasi pokoknya adalah rasa kepercayaan yang dimiliki oleh bank terhadap nasabahnya. Rasa kepercayaan berguna dalam rangka perkembangan yang menyeluruh dalam mendapatkan atau memperoleh keyakinan untuk terlibat dalam suatu hubungan atau perikatan perjanjian kredit antara bank dan nasabah

\footnotetext{
${ }^{1}$ Materi Kuliah Hukum Perbankan disampaikan oleh Dr. Surach Winarni, S.H.,M.H di Pascasarjana Fakultas Hukum Universitas Gadjah Mada, Pada Tanggal 27 Februari 2016

${ }^{2}$ Rachmat Firdaus dan Maya Ariyanti, 2011, Manajemen Perkreditan Bank Umum, Alfabeta, Bandung, hlm. 4.

${ }^{3}$ Neni Sri Imaniyati,2010,Pengantar Hukum Perbankan Indonesia, Refika Aditama, Bandung, hlm. 138
} 
Namun, penyaluran kredit oleh Bank kepada masyarakat kenyataannya tidak selalu berjalan dengan baik. Walaupun dalam pemberian kredit, Bank telah melakukan secara selektif namun bank sering dihadapkan pada dengan resiko kredit yaitu ketidakmampuan debitur untuk mengembalikan kredit tepat pada waktunya seperti yang di perjanjikan. Dalam tulisan ini akan dibahas tentang apa resiko hukum yang muncul dalam hal pemberian kredit oleh Perbankan dan bagaimana bentuk mitigasi resiko kredit oleh perbankan

\section{METODE PENELITIAN}

\section{A. Jenis Penelitian}

Jenis Penelitian yang digunakan adalah Penelitian Hukum Normatif, yaitu penelitian kepustakaan yang meneliti data sekunder.

\section{B. Sumber Data}

Sumber data yang digunakan dalam penelitian hukum normatif adalah data sekunder yang terdiri dari bahan hukum primer, bahan hukum sekunder, dan bahan hukum tersier.

a. Bahan Hukum primer terdiri dari peraturan perundang-undangan yang berakitan dengan masalah yang diteliti yaitu :

1) Undang-Undang Nomor 7 Tahun 19992 Tentang Perbankan jo. UndangUndang Nomor 10 Tahun 1998 Tentang Perbankan

2) Surat Edaran Bank Indonesia (SBI) Nomor 23 /12/BPPP Tanggal 28 februari 1991

3) Surat Keputusan Nomor 28/37/KEP/DIR Tanggal 10 Juli 1995 Tentang Informasi debitur Bank Umum

b. Bahan Hukum Sekunder, terdiri dari Buku-Buku, jurnal ilmiah, dan artikel yang berhubungan dengan perbankan.

c. Bahan hukum tersier, terdiri dari Kamus Hukum dan Kamus Besar Bahasa Indonesia.

\section{Pengumpulan Data}

Data sekunder diperoleh dengan studi dokumen menggunakan metode dokumentasi yaitu dilakukan dengan mengumpulkan, mengkaji, dan mengolah 
literatur, peraturan perundang-undangan maupun artikel, jurnal, karya ilmiah sebagai penunjang teori dalam penulisan serta pembahasan penelitian yang berkaitan dengan Kredit Perbankan

\section{Analisis Data}

Data yang diperoleh dari penelitian ini, baik dari data sekunder dan data primer di deskripsikan untuk kemudian dianalisis secara kualitatif. Dalam analisis kualitatif yang digunakan dalam penelitian ini diuraikan secara deskriptif sehingga diperoleh gambaran tentang mitigasi resiko kredit perbankan.

\section{RESIKO HUKUM DALAM PEMBERIAN KREDIT OLEH PERBANKAN}

Pengertian resiko menurut bank Indonesia adalah potensi kerugian akibat terjadinya suatu peristiwa (event) tertentu. ${ }^{4}$

Resiko juga dapat didefinisakan dalam 3 hal, yaitu : ${ }^{5}$

a. Keadaan yang mengarah kepada sekumpulan hasil khusus dimana hasilnya dapat diperoleh dengan kemungkinan yang telah diketahui oleh pengambil keputusan.

b. Variasi dalam keuntungan penjualan atau variable kuangan lainnya

c. Kemungkinan dari sebuah masalah keuangan yang mempengaruhi kinerja operasi perusahaan, atau posisi keuangan seperti resiko ekonomi, ketidakpastian politik, dan masalah industri.

Adapun kata kredit berasal dari bahasa latin credere yang berarti kepercayaan, dan kepercayaanlah yang terkandung di dalam perkreditan, antara pemberi dan penerima kredit. ${ }^{6}$

Kredit bank adalah semua realisasi pemberian kredit dalam bentuk rupiah maupun valuta asing kepada pihak ketiga bukan bank termasuk kepada pegawai bank sendiri

\footnotetext{
${ }^{4}$ Peraturan Bank Indonesia (PBI) Nomor 11/25/PBI/2009 Tanggal 1 juli 2009 Tentang Perubahan Atas PBI nomor 5/8/2003 Tentang Penerapan Manajemen Resiko Bagi Bank Umum

${ }^{5}$ Irfan Fahmi, 2011, Manajeman Resiko Teori Kasus dan Solusi, Alfabeta, Bandung, hlm. 2

${ }^{6}$ O.P. Simorangkir, 1986, Seluk Beluk Bank Komersial, Aksara Persada Indonesia, Jakarta, $\operatorname{hlm} .91$
} 
serta pembelian surat berharga yang disertai dengan note purchase agreement, pengambilalihan tagihan dalam rangka anjak piutang dan cerukan. ${ }^{7}$

Adapun karakter dari masing-masing jenis kredit adalah sebagai berikut : ${ }^{8}$

a. Kredit modal kerja, adalah kredit jangka pendek yang diberikan untuk membiayai kebutuhan modal kerja sari suatu perusahaan

b. Kredit Investasi, adalah kredit jangka menengah dan jangka panjang dalam rangka membiayai pengadaan aktiva tetap suatu perusahaan.

c. Kredit konsumsi,adalah kredit yang diberikan kepada masyarakat .

Resiko terhadap bank dapat berupa : ${ }^{9}$

a. Credit Risk, yang sangat mendasar dari semua product market risk suatu bank, karena resiko ini merupakan erosi nilai yang disebabkan oleh terjadinya wanprestasi atau nonpayment dari debitur. Jadi, debitur tidak mau atau tidak mampu memenuhi kewajiban membayar bunga atau utang pokok atau angsuran utang kreditnya atau tidak prospek mampu mebayar.

b. Strategic (Business) Risk, yaitu resiko yang meliputi seluruh bidang usaha, berupa kemungkinan kalah bersaing atau sudah ketinggalan dalam bersaing. Dapat pula terjadi bahwa sebuah bank tidak siap atau tidak sanggup bersaing ata line of business yang baru, seperti halnya credit card, dimana bank tersebut terhambat memasuki bidang tersebut

c. Regulatory Risk, yaitu resiko yang berkaitan dengan berbagai peraturan atau perundang-undangan yang menjadi rambu-rambu kegiatan perbankan. Bisnisn Bank merupakan bisnis yang bergerak dalam jasa keuangan yang amat banya regulasinya (highly regulated financial services)

d. Operating Risk, yaitu resiko yang banyak kaitannya dengan sistem dan prosedur yang kurang layak atau tepat dan mungkin menyebabkan kerugian atau menurunkan nilai services yang diberikan kepada nasabah.

7 Zainal Asikin, 1997, Pokok-Pokok Hukum Perbankan di Indonesia, PT Raja Grafindo Persada, Jakarta, hlm. 57

${ }^{8}$ Ibid

${ }^{9}$ Mohammad Tjoekam, 2000, Perkreditan Bisnis Inti Bank Komersial, PT Gramedia Pustaka Utama, Jakarta, hlm. 35 
e. Commodity Risk, yaitu resiko yang berkaitan dengan harga-harga commodity. Harga Komoditas mempunyai pengaruh besar terhadap kegiatan perbankan dan kegiatan lembaga keuangan lainnya yang sulit di deteksi terlebih dahulu (unpredctable).

f.Human Resourches Risk, yaitu resiko yang berkaitan dengan faktor kelemahan atau kesalahan yang ditimbulkan tindakan manusia. Resiko ini sukar diukur karena resiko atas nilai-nilai kemanusiaan tidak bersifat nyata.

g. Legal Risk, yaitu resiko yang timbul dari legal system. Legal Risk sulit untuk dilihat dan hampir tidak dapat diperhitungkan

Resiko dapat datang darimana saja dan dari berbagai bentuk keputusan bisnis perbankan seperti keputusan penyaluran kredit, penerbitan kartu kredit, valuta asing, inkaso dan berbagai keputusan di bidang financial lainnya.

Salah satu jenis resiko yang dapat menimpa Bank adalah resiko hukum atas pemberian kredit oleh bank. Pemberian kredit nyatanya memang merupakan kegiatan perbankan yang mengandung banyak resiko yang sukar untuk diprediksi sebelumnya.

Resiko yang muncul dalam perbankan terkhususnya dalam resiko pemberian kerdit diakibatkan oleh adanya jangka waktu yang memisahkan antara pemberian prestasi dan kontraprestasi yang akan diterima dikemudian hari. Semakin lama kredit diberikan semakin tinggi pula tingkat resikonya karena sejauh-jauhnya kemampuan manusia dalam memprediksi kemungkinan-kemungkinan yang akan terjadi setelah bank menyalurkan kredit. Banyak resiko-resiko yang bisa saja muncul dikemudian hari dan adanya ketidaktentuan yang tidak bisa diperhitungkan.

Adapun Resiko hukum dalam pemberian kredit oleh bank, dapat dikategorikan sebagai berikut $:^{10}$

a. Resiko hukum yang dapat diindetifikasikan, diukur dan bahkan dapat dipersiapkan bentuk pengendaliannya sejak tahap awal proses pemberan kredit dilakukan

b. Resiko hukum yang tidak bisa diperkirakan sebelumnya, bahkan sejak awal resiko tersebut tidak dianggap sebagai bentuk resiko hukum, yang harus

${ }^{10}$ Neni Rachmawaty, Peran Audit Internal Bank Dalam Pengendalian Resiko Hukum Pada Proses Pemberian Kredit Oleh Bank, Universitas Gadjah Mada, Yogyakarta, hlm. 83 
diwaspadai sehingga di kemudian hari bisa menimbulkan efek kerugian yang cukup besar, baik secara materiil maupun yang berkaitan dengan reputasi bank.

Resiko hukum yang sering sekali muncul dalam hal pemberian kredit adalah adanya permasalahan kredit, setiap bank pasti pernah mengalami permasalahan kredit, kredit yang bermasalah sesungguhnya mengandung resiko dalam setiap pemberiannya, resiko tersebut dapat berupa keadaan dimana pihak nasabah atau debitur dimana kredit tidak dapat dikembalikan pada tepat pada waktunya, dan hal ini tidak dapat dihindari oleh bank karena pemberian kredit merupakan salah satu bentuk dari kegiatan perbankan.

Kredit dikategorikan sebagai kredit yang bermasalah adalah apabila kualitas kredit tersebut tergolong pada tingkat kolektibilitas kurang lancar, diragukan, dan macet. Kolekttibilitas kredit telah ditentukan oleh Bank Indonesia sesuai dengan Surat Edaran Bank Indonesia (SBI) Nomor 23 /12/BPPP Tanggal 28 februari 1991, diantaranya yaitu

a. Kredit kurang lancar, adalah suatu kredit yang memenuhi kriteria sebagai berikut :

1. Kredit diluar KPR harus memenuhi syarat-sayarat yaitu terdapat tunggakan angsuran pokok yang melampaui 1 bulan (tapi belum melampaui 2 bulan) bagi kredit yang angsurannya 1 bulan atau melampaui 3 bulann (tapi belum melampaui 6 bulan) bagi kredit masa angsurannya ditetapkan bulanan atau 2 bulanan atau 3 bulanan. Terdapat cerukan karena penarikan yang jangka waktunya telah melampaui 15 hari kerja tetapi belum melampaui 30 hari kerja. Terdapat tunggakan bunga melampaui 3 bulan bagi yang angsuran kreditnya 1 bulan, atau melampaui 3 bulan tetapi belum melampaui 6 bhlan bagi angsuran kreditnya yang melebihi 1 bulan.

2. Bagi kredit KPR terdapat tunggakan angsuran pokok telah melampaui 6 bulan tapi belum melampaui 9 bulan

3. Kredit tanpa angsuran, yaitu kredit belum jatuh tempo dan terdapat tunggakan bunga melampaui 6 bulan atau terdapat penambahan plafon atau kredit baru yang dimaksudkan untuk melunasi tunggakan bunga. Kredit jatuh tempo dan belum dibayarm tetapi belum melampaui 3 bulan. Selain itu, terdapat cerukan 
karena penarikan tetap jangka waktunya telah melampaui 15 hari kerja tetapi belum melampaui 30 hari kerja.

4. Kredit yang diselamatkan, yaitu kredit yang mempunyai ceruka karena penarikan tetap jangka waktunya telah melampaui 15 hari kerja dan belum melampaui 30 hari kerja.

b. Kredit yang diragukan yaitu, kredit yang tidak memenuhi kriteria lancar atau kurang lancar, tetapi kredit tersebut dapat diselamatkan dan agunannya bernilai sekurang-kurangnya $75 \%$ dari utang debitur atau kredit tidak dapat diselamatkan tapi agunannya masih bernilai sekurang-kurangnya 100\%

c. Kredit macet, yaitu :

1. Kredit yang tidak memenuhi kreteria lancar, kurang lancar, dan diragukan.

2. Memenuhi kriteria diragukan tetapi dalam jangka waktu 21 bulan sejak digolongkan diragukan ada pelunanas atau usaha penyelamatan kredit.

3. Kredit tersebut penyelesaiannya telah diserahkan kepada Pengadilan Negeri atau abdan Urusan Piutang Negara (BUPN) atau telah diajukan penggantian ganti rugi kepada perusahaan asuransi kredit.

Kredit bermasalah yang dapat terjadi pada bank berpotensi terhadap kerugian bank yang bersangkutan ${ }^{11}$, karenanya sudah seyogyanya bank sebelum memberikan kredit harus sudah bisa mempertimbangkan resiko-resiko apa saja yang akan muncul dengan adanya pemberian kredit tersebut.

\section{MITIGASI RESIKO KREDIT PERBANKAN}

Dalam setiap pemberian kredit tentu saja mengandung resiko, resiko dalam hal ini adalah kredit yang bermasalah. Kredit merupakan risk asset bagi bank karena asset bank dikuasai oleh pihak diluar bank yaitu nasabah yang merupakan debitur. Setiap bank menginginkan dan berusaha keras agar kualitas assets tersebut tetap produktif atau collectable. Namun kredit yang disalurkan oleh bank terkadang tidak dapat dikembalikan tepat pada waktu atau sesuai dengan yang telah di perjanjikan sehingga terkadang disebut sebagai kredit bermasalah.

${ }^{11}$ M. Bahsan, 2007, Hukum Jaminan dan Jaminan Kredit Perbankan Indonesia, Rajawali Pres, Jakarta, hlm. 101 
Resiko kredit perlu mendapat penanganan yang tepat. Hal ini dikarenakan resiko kredit merupakan resiko yang paling popular dan paling nyata sekaligus berdampak terbesar bagi bank. Resiko kredit ini berpotensi menjadikan sebuah kredit menjadi bermasalah. Namun resiko tersebut dapat diminimalisir keberadaannya. Penyaluran kredit kepada masyarakat baik itu kepada perorangan ataupun untuk badan usaha tentu saja dilakukan secara hati-hati, teliti dan cermat.

Sebelum melakukan pemberian kredit hendaknya pihak Bank selaku kreditur melakukan analisis yang mendalam.

Untuk mencegah terjadinya kredit yang bermasalah di kemudian hari, penilaian suatu bank untuk memberikan persetujuan terhadap suatu permohonan kredit dilakukan dengan berpedoman pada analisis prinsip 4P dan 5C dan 3R. Adapun analisis prinsip 4C yaitu : ${ }^{12}$

a. Personality, dalam hal ini pihak bank mencari data secara lengkap mengenai kepribadian si pemohon kredit, antara mengenai riwayat hidupnya, pengalamannya dalam berusaha, pergaulan dalam masyarakat, dan lain-lain.

b. Purpose, selain mengenai kepribadian dari pemohon kredit, bak juga harus mencari data tentang tujuan atau penggunaan kredit tersebut seusai line of business kredit bank yang bersangkutan.

c. Prospect, dalam hal ini bank melakukan analisis secara cermat dan mendalam tentang bentuk usaha yang akan dilakukan oleh pemohon kredit.

d. Payment, bahwa dalam penyaluran kredit bank harus mengetahui dengan jelas mengenai kemampuan dari pemohon kredit untuk melunasi utang kredit dalam jumlah dan jangka waktu yang ditentukan.

Adapun penjelasan untuk analisis dengan prinsip 5C adalah sebagai berikut $:^{13}$

a. Character, suatu keyakinan bahwa sifat atau watak dari orang-orang yang akan diberikan kredit benar-benar dapat dipercaya, hal ini tercermin dari latar belakang si nasabah baik yang bersifat latar belakang pekerjaan maupun yang bersifat pribadi

\footnotetext{
${ }^{12}$ Hermansyah, 2005, Hukum Perbankan Nasional Indonesia, Prenada Media Group, Jakarta, hlm. 63

${ }^{13}$ Kasmir, 2002, Bank \& Lembaga Keuangan Lainnya, PT RajaGrafindo Persada, Jakarta, hlm. 104
} 
b. Capacity, untuk melihat nasabah dalam kemampuannya dalam bidang bisnis yang dihubungkan dengan pendidikannya, kemampuan bisnis juga diukur dengan kemampuannya dalam memahami tentang ketentuan-ketentuan pemerintah.

c. Capital, untuk melihat penggunaan modal apakah efektif, dilihat dari laporan keuangan (neraca dan laporan laba rugi) dengan melakukan pengukuran seperti likuiditas, solvabilitas, rentabilitas, dan ukuran lainnya.

d. Collateral, merupakan jaminan yang diberikan calon nasabah baik yang bersifat fisik maupun non fisik. Jaminan hendaknya melebihi jumlah kredit yang diberikan. Jaminana harus diteliti keabsahannya, sehingga jika terjadi suatu masalah, maka jaminan yang dititipkan akan dapat dipergunakan secepat mungkin.

e. Condition of economy, dalam menlilai kredit hendaknya dinilai juga kondisi ekonomi dan politik sekarang dan dimasa yang akan datang sesuai sektor masing-masing,serta prospek usaha dari sektor yang dijalankan. Penialain prospek bidang usaha yang dibiayai hendaknya benar-benar memiliki prospek yang baik, sehingga kemungkinan kredit tersebut bermasalah relatif kecil.

Selain itu, untuk memitigasi resiko yang akan muncul dari adanya penyaluran kredit perbankan maka bank dalam memberikan kredit juga menggunakan prinsip 3R : ${ }^{14}$

a. Returns, yaitu hasil yang diperoleh debitur dalam hal ketika kredit telah dimanfaatkan dan dapat diantisiapsi oleh calon kreditur. Artinya, perolehan tersebut mencukupi untuk membayar keperluan perusahaan yang lain seperi cash flow, kredit lain jika ada, dan sebagainya

b. Repayment, yaitu kemampuan bayar dari pihak debitur tentu saja juga mesti dipertimbangkan, dan apakah kemampuan bayar itu match dengan schedule pembayaran kembali dari kredit yang diberikan itu.

c. Risk Bearing Ability, yaitu sejauh mana terdapatnya kemampuan debitur untuk menanggung resiko. Misalnya dalam hal terjadinya hal-hal diluar antisipasi kedua belah pihak. Terutama jika dapat menyebabkan timbulmya kredit macet.

${ }^{14}$ Munir Fuady, 1996, Hukum Perkreditan Kontemporer, Penerbit PT Cipta Aditya Bakti, Bandung, hlm. 25-27 
Untuk itu harus diperhitungkan apakah jaminana dan/ asuransi barang atau kredit sudah cukup aman untuk menutupi resiko tersebut.

Bank dalam rangka pemberian kreditnya kepada seorang nasabah atau calon debitur sangat memerlukan informasi mengenai 4P, 5C, dan 3R tersebut, dan informasi tersebut tidak cukup di dapatkan dari atau yang terdapat dalam dokumen aplikasi kredit, tapi harus dilakukan pencarian yang lebih mendalam lagi dari berbagai sumber. Hal demikian merupakan kebutuhan dalam mendukung pengkajian keuangan (financial recasting) untuk pemberian kredit tersebut. ${ }^{15}$

Dengan demikian bank sangat memerlukan informasi yang mendalam dan lengkap tentang calon debitur, kebutuhan akan informasi tersebut sebenanrnya telah dipenuhi oleh pusat informasi yang telah dirintis oleh Bank Indonesia. Bank Indonesia berdasarkan Surat Keputusan Nomor 28/37/KEP/DIR Tanggal 10 Juli 1995 Tentang Informasi debitur Bank Umum, telah mempunyai suatu sistem dan prosedr informasi tersendiri.

Analisis yang mendalam sangat berperan penting sebelum bank menyalurkan menyalurkan kredit terhadap nasabah. Permasalahan yang ada meskipun tidak bisa dihindari namun bisa untuk diminimalisir keberadaannya. Untuk itu bank Perlu menerapkan manajemen terhadap resiko kredit yang sering muncul dalam penyaluran kredit terhadap nasabah.

Manajemen resiko dapat dijabarkan sebagai proses pengukuran atau penilaian resiko serta pengembangan strategi pengelolaannya. Bank perlu menerapkan manajemen resiko yang akan mendukung efektivitas kerangka pengawasan bank berbasis resiko ditengah semakin kompleksnya produk dan aktivitas perbankan terutama dalam hal penyaluran kredit.

Adanya mitigasi resiko dalam penyaluran kredit sebenarnya untuk mengetahui lebih dini bahaya yang mungkin saja terjadi dan menimpa bank sebagai akibat adanya penyaluran kredit terhadap nasabah bank. Selain dengan melakukan analisis yang mendalam menggunakan analisis formula 4P, 5C, dan 3R, manajemen resiko yang dapat di terapkan untuk meminimalisir kerugian yang mungkin saja muncul dari

15 Muhammad Djumhana, 2008, Asas-Asas Hukum Perbankan Indonesia, Penerbit Citra Aditya Bakti, hlm. 268. 
penyaluran kredit dengan mengetahui lebih dini upaya-upaya yang harus dilakukan dan dipersiapkan oleh manajemen bank untuk terlindungi dari resiko-resiko tersebut.

Upaya-upaya yang dapat dilakukan adalah dengan mengetahui faktor-faktor produksi yang paling rentan terhadap resiko, mengetahui kebijaksanaan perkreditan yang diambil manajemen untuk mengantisiapsi akibat negatif dari resiko tersebut, dan dalam perencanaan kredit diarahkan memilih bidang-bidang usaha yang tingkat resiko yang rendah dan sebagai alat penetapan suku bunga kredit.

Namun terkadang, meskipun telah dilakukan analisis yang mendalam dalam pemberian kredit, tapi munculnya resiko kredit bermasalah tidak dapat dihindari, hal ini bisa saja terjadi, karena dari pihak perbankan sendiri dalam melakukan analisisnya pihak analisnya kurang teliti sehingga apa yang seharusnya bisa dihindari dengan di prediksi sebelumnya tidak dilakukan, hal lain juga yang bisa saja terjadi yaitu adanya kolusi akibat adanya hubungan anatara pihak yang menganalisis kredit dengan pihak nasabah yang memberikan permohonan kredit.

\section{PENUTUP}

1. Sektor Perbankan merupakan sektor yang sangat High Risk, artinya sangat rentan terhadap resiko-resiko, salah satu resiko yang sangat sulit untuk dihindari adalah resiko di bidang perkreditan. Kegiatan penyaluran kredit terhadap masyarakat yang merupakan nasabah bank adalah kegiatan perbankan yang akan terus berlangsung, dan selama kegiatan penyaluran kredit berlangsung terus menerus maka resiko-resiko perbankan di bidang kredit akan terus ada

2. Resiko di bidang perbankan tidak dapat dihindari ataupun dihilangkan namun dapat diminimalisir keberadaannya, maka pihak bank seharusnya melakukan analisis yang cukup mendalam sebelum menyalurkan kredit dengan menggunakan prinsip 4P, 5C, dan 3R. Prinsip-prinsip tersebut merupakan dasar dalam menyalurkan kredit agar kredit yang disalurkan tidak menimbulkan masalah di kemudian hari. 


\section{DAFTAR PUSTAKA}

Asikin, Zainal. 1997. Pokok-Pokok Hukum Perbankan di Indonesia,Jakarta : PT Raja Grafindo Persada.

Djumhana, Muhammad . 2008. Asas-Asas Hukum Perbankan Indonesia. Bandung : Penerbit Citra Aditya Bakti.

Fahmi, Irfan. 2011. Manajeman Resiko Teori Kasus dan Solusi. Bandung : Alfabeta

Firdaus, Rachmat dan Maya Ariyanti . 2011. Manajemen Perkreditan Bank Umum. Bandung : Alfabeta

Fuady, Munir. 1996. Hukum Perkreditan Kontemporer. Bandung : Penerbit PT Cipta Aditya Bakti

Hermansyah. 2005. Hukum Perbankan Nasional Indonesia. Jakarta : Prenada Media Group

Kasmir. 2002. Bank \& Lembaga Keuangan Lainnya. Jakarta : PT RajaGrafindo Persada

M. Bahsan. 2007. Hukum Jaminan dan Jaminan Kredit Perbankan Indonesia. Jakarta : Rajawali Press

Simorangkir, O.P. 1986. Seluk Beluk Bank Komersial. Jakarta : Aksara Persada Indonesia

Sri Imaniyati, Neni. 2010. Pengantar Hukum Perbankan Indonesia. Bandung : Refika Aditama

Tjoekam, Mohammad. 2000. Perkreditan Bisnis Inti Bank Komersial. Jakarta : PT Gramedia Pustaka Utama

Rachmawaty, Neni. 2014. Peran Audit Internal Bank Dalam Pengendalian Resiko Hukum Pada Proses Pemberian Kredit Oleh Bank. Yogyakarta :Universitas Gadjah Mada

Surat Edaran Bank Indonesia (SBI) Nomor 23 /12/BPPP Tanggal 28 februari 1991

Surat Keputusan Nomor 28/37/KEP/DIR Tanggal 10 Juli 1995 Tentang Informasi debitur Bank Umum 